\title{
My Mother Predicts Travel to Exotic Destinations
}

Shut up and study harder.

You'd have to be a fool to get these grades. Another $F$ and it's military school.

Or better yet, enlistand let the army try to feed you. Then you can gripe about their food and what they guaranteed you.

All you do here is snarland stomp downstairs for chow You're eating us into the poorhouse. You're like a garbage scow.

Yes, all you do is eatand chase your cheap blonde slut. Do you think that minx will visit you when the prison door slams shut?

If you tried, you might enjoy girls who study books, hold down a steady job-or twoand maybe even cook.

But they don't have dyed hair and fake breasts like that tart who'll have you stealing from the till and robbing Quickee-Mart 
to keep her pimp in cocaine and her babies in day-care.

And she'll be with another man when you reach the electric chair.

And only Mom will be there when you lose your appealto tell you not to gulp your food when you eat your final meal. 